\title{
The Impact of Tourism Experience Co-creation on The Attachment to The Egyptian Destination
}

\author{
Hebat Allah Ai Sayed Gaafar \\ Associate professor - Tourism Studies Dept. \\ Faculty of Tourism and Hotels-University of Sadat City
}

\begin{abstract}
In the last years, tourists want to plan their trips and co-create their experience, which starts when they are still in their home country and collect information, and continues when have returned back. Destinations have begun to involve tourists in designing their trips and creating their whole tourism experience. As effective link or relation between tourists and particular destinations can build strong connections with certain destinations, which may lead to destination attachment. Starting from these thoughts, the main aim of this paper is to investigate the relation between tourism experience co-creation and the attachment to the Egyptian destination. The research applied quantitative approach, a questionnaire was designed, and data was collected from 575 tourists visiting Hurghada and Sharm el Skeikh. Study results revealed that the Egyptian destination has succeeded in boosting the co-creation of tourism experience. The Egyptian destination has achieved a high level of destination attachment to their tourists. Also, results showed that there is a strong significant positive correlation between tourism experience co-creation and destination attachment. This study contributes to the Egyptian destination managers by providing the important aspects that improve the co-creation of tourism experience, and which of them can affect the degree of attachment to the Egyptian destination.
\end{abstract}

\section{Keywords}

Tourism experience co-creation, destination attachment, the Egyptian destination

\section{Introduction}

Co-creation is a demand- centric and communicating process that refers to actors creating something in cooperation with or induced by others (Jaakkola et al., 2015). This process may accomplish success and satisfaction for both the tourist and the destination if the former is the center of attention (Yen et al., 2004). Whereas, the continuous interaction with the tourists enables 


\section{The Impact of Tourism Experience Co-creation on The Attachment to The Egyptian Destination}

tourism destinations to learn from them (Buonincontri et al., 2017). The creation of a focused dialog with tourists and the combination of their personal resources with the destination portray experience co-creation (Prahalad \& Ramaswamy, 2004).

Experience co-creation is the process of the collaboration between tourists and destinations to create experiences (Mathis et al., 2016). Experience cocreation concentrates on tourists as active members in building their own experiences (Jaakkola et al., 2015). The concept of co-creation of an experience stresses on the idea of the customer as a value creator, collaborating with the destination to "co-create" value (Prebensen et al., 2013).

Prahalad \& Ramaswamy (2004: p. 7) defined experience co-creation as a combined creation of value by the destination and the tourists, allowing the customers to compose service experiences in order to fit their desires. According to Prebensen et al. (2013) the more the tourist is involved in the co-creation process through effort and time, the more positive experience he/she will gain.

Previous studies have focused on the successful role of tourism experience co-creation in achieving competitive advantage (Bharwani \& Jauhari, 2013; Binkhorst \& Den Dekker, 2009; King, 2017; Morgan et al., 2009; Schmidt, 2010). Other researchers highlight the travel agencies support as an antecedent of tourism experience co-creation, and tourist satisfaction with the provided services, tourist loyalty, and the level of expenditures as consequences (Buonincontri et al., 2017; Grissemann and Stokburger-Sauer, 2012; Lee, 2012; Mathis et al., 2016). On the other hand, other researchers have given a little consideration to experience co-creation and place attachment, such as the study by Suntikul and Jachna (2016) that emphasized on value co-creation of tourism activities and place attachment in Macao - a city locates on China's southern coast. To the best of my knowledge, the empirical research on the role of positive co-creating tourism experience and tourism destination attachment is still limited. The way in which tourism experience co-creation creates attachment to tourism destination has not yet been fully studied.

Based on this concept, the aims of this research are to: a) understand the dimensions of the construct of tourism experience co-creation; b) identify the destination attachment factors (place identity and place dependence); c) address the correlation between tourism experience co-creation and destination attachment. 
Corresponding to these research aims; the paper first gives an in-depth literature review. Second, the methodology and data collection process used are showed. Subsequently, the paper presents the research results on the impact of tourism experiences co-creation and the attachment to the Egyptian tourism destination. The results of this research may help destination managers establish policies; not only for improving tourism experience cocreation but also supporting attachment to the Egyptian tourism destination.

\section{Tourism experience and co-creation}

Nowadays, tourists have active role in forming their visits, they design their travel online, choose their accommodation, search the unique tourist attractions and investigate the online reviews. As, they want to invest their own resources like time, money, or ability to practice activities at the destination (Neuhofer, 2016). Subsequently, tourism destinations have realized the power of tourists and the significance of implementing a demand-centric approach in which co-creation is the main factor (Mathis et al., 2016; Minkiewicz et al., 2014).

Many researchers identify the basis of tourism experience co-creation as follows: (a) the communication between tourists and service providers; (b) the active involvement of tourists; (c) tourists' desire to share their experience with locals at destination, their relatives, friends, other tourists and unknown users through the Internet, social media, and other tools (Binkhorst and Den Dekker 2009; Darmer andSundbo, 2008; Neuhofer et al. 2012). Tourists like to co-create their whole experience, which begins when they are still at home and collect information, and continues after have returned home (Aho, 2001).

The tourism experience process is classified into three phases (Buonincontri, and Micera, 2016):

(a) Pre-visit, in this phase the tourist still at his own country, seeks information, selects the destination, and buys the package.

(b) During visit, when the tourist arrives and practices the activities within the destination.

(c) Post-visit, when the tourist returns to his country, expresses his experience and shares his memories.

Most of tourism destinations consider experience co-creation as a vital factor for achieving success and competitiveness, especially, after the modern active role of tourists. In order to achieve positive tourism experience co-creation, destination managers should stimulate and offer tourists important information and necessary resources. According to Minkiewicz et al. (2014) tourist interaction is considered as an important factor that may boost tourists' 


\section{The Impact of Tourism Experience Co-creation on The Attachment to The Egyptian Destination}

experience. Moreover, without customized interactions, the time and effort devoted to experience co-creation would be insignificant, and, as a result, experiences wouldn't add value for either the tourist or the destination (Chathoth et al., 2016).

\section{Destination attachment}

Destination attachment refers to the effective link or relation between tourists/ visitors and particular destinations (Hidalgo and Hernandez, 2001: p.274). As people attach to specific places through developing "feelings of possession for the resource" (Williams, 2008: p. 8). In the context of tourism, destination attachment expresses the connection between tourists and destination. If tourists attach to the destination, they will be more satisfied and tend to revisit the 2004; Jorgenson and Nickerson, 2016).

destination (George,

The degree of attachment to a destination is influenced by the emotional impact of a destination on the tourists who are attracted to. In this regard, place attachment is a symbolic link with a destination, which is shaped by providing the emotional meanings and good judgment to a specific destination. The attachment to a destination is raised from activities and relations between tourist-destination and tourist-community in a certain destination (Shamsuddin \& Ujang, 2008).

There are many factors that influence the destination attachment (Hashemnezhad et al., 2013):

(a) Physical factors: these factors are related to the features of a destination; facilities, provided services, natural environment, accommodations, attractions, accessibility, transportations, and interaction and activity types.

(b) Interaction and activity features: according to Yuksel et al., (2010) the interaction between human to human and human to destination play a vital role in generating destination attachment. Indeed, destination activities result in place meaning and place meaning generate place attachment. Also, periodical events and festivals held on a destination are considered as important factors for improving destination attachment

(c) Social factors: relate to tourists' involvement, social network engagement and social compatibility in destination.

(d) Memories and experiences: Entirely, destination attachment took place when tourists have positive and powerful experience in that destination. 
There are two conceptualizations of destination attachment: - place identity and place dependence. "Place identity" relates to one's emotional relation to a place, whereas "Place dependence" refers to the appropriateness of a place to satisfy one's functional needs and aims (Ujang, 2012 ). In the context of tourism, destination attachment is linked to tourist/visitor satisfaction and loyalty to destinations (Wolf et al., 2014; Yuksel et al., 2010)

Destination managers can boost tourists' feeling of destination attachment through offering an inclusive tourism experience that involves tourists emotionally and cognitively (Tsai, 2012). The level of tourists' involvement with a destination is an indicator of the intensity of their destination attachment (Gross \& Brown, 2008). Activities are considered one of the most important external stimuli of experiences, that can be practiced at the destination individually or collectively and can affect the degree of destination attachment (Suntikul \& Jachna, 2016). This research tends to join experience co-creation with destination attachment.

Experience co-creation is something that is created, while destination attachment is something that is felt (Sotiriadis, 2017). In order to link tourism experience co-creation and attachment to the Egyptian destination, the research will investigate what activities, if any, affect the formation of destination attachment. The research has proposed the following hypotheses: H1: There is a significant relationship between practicing activities at the Egyptian destination and the destination attachment.

$\mathrm{H} 2$ : There is a significant positive correlation between tourism experience cocreation and attachment to the Egyptian destination.

\section{Methodology}

The aim of the study was to investigate the correlation between tourism experience co-creation for foreign tourists and their level of attachment to the Egyptian destination. The tourists were surveyed during the winter season of 2019. In total, 950 questionnaires were handed out to the respondents with 575 completed for a response rate of $60.5 \%$. The study was conducted in Sharm el Sheikh and Hurgada because they are considered of the most famous destinations in Egypt, characterized by their hedonic, natural beauty, and relaxation. In this research, simple random sampling is applied as every member of the population is similarly likely to be chosen.

The survey was conducted with the help of receptionists in several hotels at Sharm El Sheikh (12 hotels) and Hurghada (10 hotels). Hotels were selected because of their managers' approval on conducting the research. The questionnaire was written in English; all the foreign respondents were able to understand the English language. The experience co-creation was measured 


\section{The Impact of Tourism Experience Co-creation on The Attachment to The Egyptian Destination}

by 12 items scale, while destination attachment was measured utilizing two attributes: place dependence and place identity. Place dependence was measured by 6 items scale, and place identity was measured by 4 items scale.

The constructs of the variables were measured by a set of multiple five-point Likert scales ranging from "strongly agree" (5) to "strongly disagree" (1) (Table 1). The usage of five-point scales is because of making the research's results similar with the previous studies from which the items were adapted (Buonincontri et al., 2017; Grissemannaut and Sauer, 2012; Jorgenson \& Nickerson, 2016; Mathis et al., 2016; Peterson et al., 2005; Suntikul and Jachna, 2016; Wang et al., 2014; Williams \& Vaske, 2003). Additionally, as asserted by Revilla et al. (2014), five-point scales give better quality data than scales with more points. 
Table (1): Measurement Model of the research

\begin{tabular}{|c|c|c|}
\hline \multirow[b]{2}{*}{$\begin{array}{l}\text { Constructs } \\
\text { Tourism } \\
\text { experience } \\
\text { Co-creation }\end{array}$} & Items & Authors \\
\hline & $\begin{array}{l}\text { I've been actively participated in organizing my visit. } \\
\text { I've used my experience from previous trips in order } \\
\text { to arrange this trip and make it better. } \\
\text { I've spent a considerable amount of money to arrange } \\
\text { this trip. } \\
\text { My tourism experience was improved because of my } \\
\text { involvement in cultural and recreational activities. } \\
\text { I've shared my experience with others during my trip. } \\
\text { I'll tell others about my experience I've had at this } \\
\text { destination. } \\
\text { I like sharing tourism experience and travel } \\
\text { knowledge throughout social media. } \\
\text { It's very easy to gain any information about this } \\
\text { destination. } \\
\text { I can book my trip on-line. } \\
\text { I like to spend more time to enjoy being at this } \\
\text { destination. } \\
\text { I like to take many photos of this destination. } \\
\text { I know the body with whom I can contact if I've } \\
\text { problems. }\end{array}$ & $\begin{array}{l}\text { Peterson et al., } \\
(2005) \text {; } \\
\text { Wang et al., } \\
(2014) \\
\text { Own elaboration }\end{array}$ \\
\hline Destination a & & \\
\hline $\begin{array}{l}\text { Destination } \\
\text { dependence }\end{array}$ & $\begin{array}{l}\text { The atmosphere at this destination is unique. } \\
\text { This destination is comfortable and enjoyable. } \\
\text { This destination is promoted as a must-see place for } \\
\text { tourists. } \\
\text { No other place can be compared with this destination. } \\
\text { I consider this destination is one of the most } \\
\text { preferable places to me. } \\
\text { This destination is very special to me. }\end{array}$ & $\begin{array}{l}\text { Jorgenson \& } \\
\text { Nickerson, } \\
\text { (2016); Suntikul } \\
\text { and Jachna, } \\
\text { (2016); } \\
\text { Williams and } \\
\text { Vaske, (2003) }\end{array}$ \\
\hline $\begin{array}{l}\text { Destination } \\
\text { identity }\end{array}$ & $\begin{array}{l}\text { I'll recommend this destination as must-see place for } \\
\text { my relatives and friends. } \\
\text { I'll remember this destination for long time after } \\
\text { travelling. } \\
\text { I've the intention to revisit this destination, If I could. } \\
\text { This destination means a lot to me and very special. }\end{array}$ & $\begin{array}{l}\text { Suntikul and } \\
\text { Jachna, (2016) } \\
\text { Williams and } \\
\text { Vaske, (2003); } \\
\text { Jorgenson and } \\
\text { Nickerson, (2016) }\end{array}$ \\
\hline
\end{tabular}

Source: Author's elaboration 


\section{The Impact of Tourism Experience Co-creation on The Attachment to The Egyptian Destination}

In conceptualizing tourism experience co-creation, several items construct was applied, combining three items that Buonincontri et al., 2017 derived from Grissemann and Stokburger-Sauer (2012), two items from Mathis et al.'s work (2016), two items from Wang et al. (2014), who derived them from Peterson et al.'s research (2005). The other five items were constructed by the author.

The six items related to place dependence were adapted from Jorgenson \& Nickerson (2016); Suntikul and Jachna (2016) and Williams \& Vaske (2003). Four items on place identity were derived from Jorgenson \& Nickerson (2016) and Williams \& Vaske (2003). All the items were perfectly checked by academic experts in tourism as well as statistics.

The questionnaire consists of three parts. The first part concerned with the respondents' demographic data. The second part contained a measurement of study constructs with five-point Likert scales. The third part included yes/no questions about the activities that tourists practiced at the Egyptian destination. The questionnaire was pretested by faculty staff and tourism researchers with specific knowledge of tourism experience co-creation and destination attachment. The questionnaire was piloted on 50 tourists, the reliability of each construct was highly reliable as shown in Table 2. According to Hair et al. (1998), a Cronbach's alpha score 0.70 or more showed that scale of measuring the research construct was reliable. After this process, the questionnaire was distributed on the tourists as there weren't any modifications.

IBM the Statistical Package for the Social Sciences (SPSS) software, version 23 was applied for data analysis.

Table (2). Reliability of the research variables

\begin{tabular}{ll}
\hline Constructs & Reliability \\
\hline Experience co creation in tourism Items & 0.851 \\
Destination attachment Items & 0.815 \\
\hline
\end{tabular}

\section{Results}

The respondents' demographic data and travel characteristics are illustrated in Table 3. Study results display that (59\%) of the respondents were males, while the females scored (41\%). With reference to the origin, the majority of respondents were from Italy $(27.1 \%)$, while the tourists from the UK achieved (19.8\%) followed by Germany (17.2\%) and Belgium (11.1\%). 36.5 $\%$ of the respondents had a bachelor's degree, and $20.3 \%$ had vocational degree; most of the respondents were employees and entrepreneurs. With reference to the participants' travel characteristics, nearly half of the sample visited the destination for the first time $(56.2 \%)$, while $11.1 \%$ was on their second visit or more. $69.4 \%$ of the participants stated that they were in Egypt 
for tourism purpose. With regards to the length of stay, $84 \%$ of the respondents stayed at the destination from 2 to 4 nights. Concerning, the respondents' ages, approximately half of the sample was youth; their ages ranged from 20 to 39 years.

Table (3): Demographic data and travel characteristics of the respondents

\begin{tabular}{lll}
\hline Variables & Freq. & $\mathbf{\%}$ \\
\hline Gender & & \\
Male & 339 & 59 \\
Female & 236 & 41
\end{tabular}

Age

$15-19$

Nationality

German

British

Italian

Dutch

Belgium

Austrian

\section{Education}

High school

Bachelor's degree

Vocational degree

Master's/ doctorate

\section{Profession}

Student

Employee

Entrepreneur

Retired

House wife

Other

No. of visits

First visit

Once before

Twice or more before 


\section{The Impact of Tourism Experience Co-creation on The Attachment to The Egyptian Destination}

\section{Purpose of the visit}

Tourism

339

69.4

Business

95

16.5

Visiting friends/ relatives

80

13.9

Other

01

0.2

Length of stay

1 night

2-4nights

The following table shows that the means of the responses to experience cocreation in tourism range from 3.24 to 4.55 , indicating a high level of tourism experience co-creation. As the statement "My tourism experience was improved because of my involvement in cultural and recreational activities" achieved the highest mean (4.55), followed by "I like to spend more time to enjoy being at this destination", "It's very easy to gain any information about this destination", "I can book my trip on-line", "I'll tell others about my experience I've had at this destination", "I've shared my experience with others during my trip" respectively. While the lowest mean scored by the following statement "I've used my experience from previous trips in order to arrange this trip and make it better". Generally, the total mean of the items corresponding to tourism experience is 4.06 , which means that the cocreation of tourism experience has been highly achieved throughout the respondents' visit to the Egyptian destination.

Table (4): Mean responses to Experience co-creation in tourism

Experience co creation in tourism items

Mean

I've been actively participated in organizing my visit

I've used my experience from previous trips in order to arrange this trip and make

it better

I've spent a considerable amount of money to arrange this trip

My tourism experience was improved because of my involvement in cultural and recreational activities

I've shared my experience with others during my trip

I'll tell others about my experience I've had at this destination

I like sharing tourism experience and travel knowledge throughout social media

It's very easy to gain any information about this destination

I can book my trip on-line

I like to spend more time to enjoy being at this destination

I like to take many photos of this destination

I know the body with whom I can contact if I've problems

Average

Based on a Likert scale from $5=$ strongly agree to $1=$ strongly disagree. 
Table 5 indicates mean responses to destination attachment. Six statements were posed in order to understand different viewpoints of respondents corresponding to destination dependence. The statement "This destination is comfortable and enjoyable" achieved the highest mean 4.27, while the statement "No other place can be compared with this destination" scored the lowest mean 3.90. On the other hand, there were four statements posed to the respondents, corresponding to the destination identity, means of the responses to these items ranges from 4.10 to 4.37 , pointing to a high level of destination identity. The average mean of these two sets is 4.12 , which representing a high level of attachment to the Egyptian destination. Generally, means of the Egyptian destination identity items are higher than those for the Egyptian destination dependence items.

Table (5): Mean responses to destination attachment

\begin{tabular}{ll}
\hline & Mean \\
\hline Destination dependence & 3.97 \\
The atmosphere at this destination is unique & 4.27 \\
This destination is comfortable and enjoyable & 4.12 \\
This destination is promoted as a must-see place for tourists & 3.90 \\
No other place can be compared with this destination & 3.95 \\
I consider this destination is one of the most preferable places to me & 3.99 \\
$\quad$ This destination is very special to me & \\
Destination identity & 4.26 \\
I'll recommend this destination as must-see place for my relatives and & \\
friends & 4.37 \\
I'll remember this destination for long time after travelling & 4.23 \\
I've the intention to revisit this destination, If I could & 4.10 \\
$\quad$ This destination means a lot to me and very special & $\mathbf{4 . 1 2}$ \\
\hline Average
\end{tabular}

Based on a Likert scale from $5=$ strongly agree to $1=$ strongly disagree.

Spearman's correlation coefficient was applied to identify the strength of a monotonic relationship between activities that tourist can practice at the Egyptian destination and level of attachment to the Egyptian destination (Table 6). The following activities "practicing a lot of recreational activities", and "interacting with local community" show strong positive significant correlation with destination attachment $\left(r^{2}=0.787\right.$ and $\left.627, p \leq 0.01\right)$. While, learning about the Egyptian destination through using guidebook or surfing the net has a weak correlation with destination attachment. Accordingly, the first hypothesis was supported. 
[Table (6): Spearman's Rho Correlation between destination attachment and activities' items

\section{attachment}

Destination

\section{Activities' items at the Egyptian destination}

Correlation

Do you use in-site signs, guidebook or on-line websites to learn more about the destination Coefficient

Sig.

Did you watch and interact with local community

$0.301^{* *}$

.000

Did you practice a lot of recreational activities

$\mathbf{0 . 6 2 7 ^ { * * * }} \quad .000$

"Correlation is significant at the 0.01 level (2-tailed). Strong correlation showed in bold

Spearman's correlation coefficient identified the strength of a monotonic relationship between tourism experience co-creation and the Egyptian destination attachment (Table 7). As, the value of Spearman correlation coefficient is $0.711(\mathrm{p}<.001)$, which confirms the strong positive correlation between tourism experience co-creation and attachment to the Egyptian destination. Therefore, the second hypothesis was supported.

Table (7): Spearman's Rho Correlation between tourism experience co-creation and attachment to the Egyptian destination

\begin{tabular}{|c|c|c|c|}
\hline \multirow{2}{*}{$\begin{array}{c}\text { Destination } \\
\text { attachment }\end{array}$} & Correlation Coefficient & $\begin{array}{c}\text { Destination } \\
\text { attachment }\end{array}$ & $\begin{array}{c}\text { Tourism } \\
\text { Experience co- } \\
\text { creation }\end{array}$ \\
\cline { 2 - 4 } & Sig & 1.000 & $.711^{* *}$ \\
\cline { 2 - 4 } $\begin{array}{c}\text { tourism experience } \\
\text { co-creation }\end{array}$ & Correlation Coefficient & $.711^{* *}$ & .000 \\
\cline { 2 - 4 } & Sig & .000 & 1.000 \\
\hline
\end{tabular}

**. Correlation is significant at the 0.01 level (2-tailed). 
Table (8): Spearman's Rho Correlation between tourism experience co-creation items and attachment to the Egyptian destination

\section{Destination attachment}

\section{Tourism experience co-creation items}

I've been actively participated in organizing my visit

I've used my experience from previous trips in order to arrange this trip and make it better

I've spent a considerable amount of money to arrange this trip

My tourism experience was improved because of my

involvement in cultural and recreational activities

I've shared my experience with others during my trip

I'll tell others about my experience I've had at this destination

I like sharing tourism experience and travel knowledge throughout social media

It's very easy to gain any information about this destination

I can book my trip on-line

I like to spend more time to enjoy being at this destination

I like to take many photos of this destination

I know the body with whom I can contact if I've problems

Correlation

Coefficient

Sig.

\begin{tabular}{ll}
$.329^{* *}$ & .000 \\
$.222^{* *}$ & .000 \\
& \\
$.787^{* *}$ & .000 \\
& \\
$.733^{* *}$ & .000 \\
& \\
$.455^{* *}$ & .000 \\
$.719^{* *}$ & .000 \\
& \\
$.740^{* *}$ & .000 \\
$.756^{* *}$ & .000 \\
$.709^{* *}$ & .000 \\
$.298^{* *}$ & .000 \\
$.195^{* *}$ & .000 \\
$.706^{* *}$ & .000 \\
\hline
\end{tabular}

Correlation is significant at the 0.01 level (2-tailed). Strong correlation showed in bold

Table 8 indicates correlations between the twelve items representing tourism experience co-creation and the destination attachment construct, with reference to the respondents' responses $(p \leq 0.01)$. The results indicate that the strongest positive correlations for the attachment to the Egyptian destination are related to the following items respectively; "I've spent a considerable amount of money to arrange this trip", "It's very easy to gain any information about this destination", "I like sharing tourism experience and travel knowledge throughout social media", "My tourism experience was improved because of my involvement in cultural and recreational activities", "I can book my trip on-line", and "I know the body with whom I can contact if I've problems". On the other hand, the following tourism experience cocreation items indicate weak correlations with destination attachment; "I've been actively participated in organizing my visit", "I've used my experience from previous trips in order to arrange this trip and make it better", "I like to spend more time to enjoy being at this destination", and "I like to take many photos of this destination". 


\section{The Impact of Tourism Experience Co-creation on The Attachment to The Egyptian Destination}

\section{Conclusion}

The concept of co-creation is valuable in defining the factors that affect tourists' experience with tourist destination, and how co-creating positive experience affect the degree of attachment to a particular destination, this topic is very important for the Egyptian destination managers. This research focused on the co-creation of tourism experiences and how it can boost the attachment to the Egyptian destination. The strong positive correlation between tourism experience co-creation and destination attachment, identified throughout this research. The tourism experience co-creation relies on the following aspects; the involvement of tourists in cultural and recreational activities, active participation in designing their trips, the provision of on-line booking, the availability of technology to share their experiences with others; relatives, friends, tourists as well as unknown users. New tourists need to co-create their whole tourism experience, which begins when they are still in their home country and collect information, and continues when have returned back to their country. The research revealed that the Egyptian destination has achieved a high level of tourism experience co-creation to the tourists. As the total mean of items of the co-creation tourism experience was very high. Furthermore, the majority of the respondents have positive experience as they want to spend more time at the Egyptian destination and like to tell the others about their tourism experience.

The results indicate that the Egyptian destination has achieved a high level of destination attachment to the tourists. Whereas, most of the respondents assured that the Egyptian destination is comfortable and enjoyable, they recommend the Egyptian destination as a must-see place for others, they will remember the destination for long time after travelling, and have the intention to revisit the Egyptian destination. Generally, the means of destination identity items were higher than the means of the destination dependence items, accordingly, the destination identity affects the level of attachment to the Egyptian destination more than the destination dependence.

Also, the research proved that there is a positive correlation between tourism experience co-creation and destination attachment. There were strong correlations between the following tourism experience co-creation items and the degree of attachment to the Egyptian destination; spending considerable amount of money to arrange the trip, the involvement of the tourists in cultural and recreational activities, the availability of technology at the destination to share experience and travel knowledge with others through social media and the Internet, the ease of access to information about the destination, the personal interaction with tourists to give information and solve problems. On the contrary, depending on previous tourism experience 
to arrange the trip, spending more time at the destination, taking many photos of the destination were found to have weak correlations with attachment to the Egyptian destination.

This research contributes to the Egyptian destination managers as it gives great attention to the elements that co-create tourists / visitors experience, and which of those elements can influence the destination attachment and maintain the loyalty. Regarding site management, the Egyptian destination managers should provide numerous activities at the tourist site to encourage the tourists' participation, and enhance the interaction with local community. For example, offering on-site amenities can improve longer stays at a site, integrating activities that are attractive to both locals and tourists, can enrich chances for communications between local community and tourists. Also, the Egyptian destination mangers should give a great consideration to the application of latest technology, it can facilitate the access to a plenty of information, provide on-line booking, share memories and experience. Technology can boost the tourism experience co-creation, which has a direct relationship with attachment to the Egyptian destination. Remarkably, the more co-creation of tourism experience the more destination attachment.

\section{References}

- Aho, S.K. (2001). Towards a general theory of touristic experiences: modelling experience process in tourism. Tourism Review, 56(4),33-37.

- Bharwani, S., \& Jauhari, V. (2013). An exploratory study of competencies required to co-create memorable customer experiences in the hospitality industry. International Journal of contemporary Hospitality Management, 25(6), 823-843.

- Binkhorst, E., \& Den Dekker, T. (2009). Agenda for co-creation tourism experience research. Journal of Hospitality Marketing and Management, 18(3), 311-327.

- Buonincontri, P. and Micera, R. (2016). The experience co-creation in smart tourism destinations: a multiple case analysis of European destinations. Inf Technol Tourism, (16), 285-315.

- Buonincontri, P.; Morvillo, A.; Okumus, F.; \& Niekerk, M. (2017). Managing the experience co-creation process in tourism destinations: Empirical findings from Naples, Tourism Management, (62), 264-277. 
- Chathoth, P. K., Ungson, G. R., Harrington, R. J., Altinay, L., \& Chan, E. S.W. (2016). Co-creation and higher order customer engagement in hospitality and tourism services. A critical review. International Journal of Contemporary Hospital Management, 28(2), 222-245.

- Darmer, P., \& Sundbo, J. (2008). Introduction to experience creation. In Sundbo, J. \& Darmer, P. (Eds.), Creating experiences in the experience economy. Cheltenham: Edward Elgar.

- George, B. P. (2004). Past visits and the intention to revisit a destination: place attachment as the mediator and novelty seeking as the moderator. Journal of Tourism Studies, 15(2), 51-66.

- Grissemann, U. S., \& Stokburger-Sauer, N. E. (2012). Customer cocreation of travel services: The role of company support and customer satisfaction with the cocreation performance. Tourism Management, 33(6), 1483-1492.

- Gross, M. J., \& Brown, G. (2008). An empirical structural model of tourists and places: progressing involvement and place attachment into tourism. Tourism Management, (29), 1141-1151.

- Hair, J. F., Jr., Anderson, R. E., Tatham, R. L., \& Black, W. C. (1998). Multivariate data analysis. Upper Saddle River, NJ: Prentice Hall.

- Hashemnezhad, H., Heidari, A. A. \& Hoseini, P. M. (2013). "Sense of Place" and "Place Attachment" A Comparative Study, International Journal of Architecture and Urban Development, (3), 512.

- Hidalgo, M. C. \& Hernandez, B. (2001). Place attachment: Conceptual and empirical questions. Journal of environmental psychology, 21(3), 273-281.

- Jaakkola, E., Helkkula, A., \& Aarikka-Stenroos, L. (2015). Service experience cocreation: conceptualization, implications, and future research directions. Journal of Service Management, 26(2), 182205. 
- Jorgenson, J.D. and Nickerson, N.P. (2016). Attachment to tourism destinations: The role of memory and place attachment. Travel and Tourism Research Association: Advancing Tourism Research Globally,1-8.

- King, C. (2017). Brand management standing out from the crowd: A review and research agenda for hospitality management. International Journal of Contemporary Hospitality Management, 29(1), 115-140.

- Lee, G. (2012). Modeling consumers' co-creation in tourism innovation. In Frow, P., Nenonen, S., Payne, A., \& Storbacka, K. (2015). Managing co-creation design: A strategic approach to innovation, British Journal of Management, (26), 463-483.

- Mathis, E. F. (2013). The effects of co-creation and satisfaction on subjective well-being. master's thesis. Temple University.

- Mathis, E. F., Kim, H. L., Uysal, M., Sirgy, J. M., \& Prebensen, N. (2016). The effect of co-creation on outcome variable. Annals of Tourism Research, (57), 62-75.

- Minkiewicz, J., Evans, J., \& Bridson, K. (2014). How do consumers co-create their experiences? An exploration in the heritage sector. Journal of Marketing Management, 30(2), 30-59.

- Morgan, M., Elbe, J., \& Curiel, J. E. (2009). Has the experience economy arrived? The views of destination managers in three visitor-dependent areas. International Journal of Tourism Research, 11 (2), 201-216.

- Neuhofer. B, Buhalis. D, \& Ladkin, A. (2012) Conceptualizing technology enhanced destination experiences. Destination Marketing Management, 1(1):36-46.

- Neuhofer, B. (2016). Value Co-creation and Co-destruction in Connected Tourist Experiences, In Versini, A. \& Schegg, R. (eds.), Information and Communication Technologies in Tourism, 769-792. DOI 10.1007/978-3-319-28231-2_56.

- Peterson, C., Park, N., \& Seligman, M. E. P. (2005). Orientations to happiness and life satisfaction: The full life versus the empty life. Journal of Happiness Studies, (6), 25-41. 
- Prahalad, C. K., \& Ramaswamy, V. (2004). Co-creation experiences: The next practice in value creation. Journal of Interactive Marketing, 18(3), 5-14.

- Prebensen, N. K., Vittersø, J., \& Dahl, T. I. (2013). Value cocreation significance of tourist resources. Annals of Tourism Research, (42), 240-261.

- Revilla, M. A., Saris,W. A., \& Krosnik, J. A. (2014). Choosing the number of categories in agree-disagree scales. Sociological Methods \& Research, 43(1), 73-97.

- Schmitt, B. H. (2010). Experience marketing: Concepts, frameworks and consumer insights. Foundations and Trends in Marketing, 5(2), 55-112.

- Shamsuddin, S., \& Ujang, N. (2008). Making places: the role of attachment in creating the sense of place for traditional streets in Malaysia. Habitat International Journal, (32), 399-409.

- Sotiriadis, M. D. (2017). Sharing tourism experiences in social media: A literature review and a set of suggested business strategies. International Journal of Contemporary Hospitality Management, 29(1), 179-225.

- Suntikul, W. \& Jachna, T. (2016). The co-creation/place attachment nexus, Tourism Management, (52), 276-286.

- Tsai, S. P. (2012). Place attachment and tourism marketing: Investigating international tourists in Singapore. International Journal of Tourism Research, (14), 139-152.

- Ujang, N. (2012). Place attachment and continuity of urban place identity. Procedia Social and Behavioral Sciences, (49), 156-167.

- Wang, X., Li, X., Li, Q., \& Peng, L. (2014). Intention of sharing travel experiences on social media: Motivations and the moderating effects of face orientation. In Presented paper at the 25th Australasian conference on information systems (2014). 
- Williams, D. (2008). Chapter 2 - Pluralities of Place: A User's Guide to Place Concepts, Theories, and Philosophies in Natural Resource Management. Understanding concepts of place in recreation research and management, 7-30.

- Williams, J \& Vaske, (2003). The measurement of place attachment: validity and generalizability of a psychometric approach. Forest science, 49 (6), 830 -840.

- Wolf, I. D., Stricker, H. K., \& Hagenloh, G. (2014). Outcomefocused national park experience management: transforming participants, promoting social wellbeing, and fostering place attachment. Journal of Sustainable Tourism, 23(3), 358-381.

- Yen, R. H., Gwinner, K. P., \& Su,W. (2004). The impact of customer participation and service expectation on Locus attributions following service failure. International Journal of Service Industry Management, 15(1), 7-26.

- Yuksel, A., Yuksel, F., \& Bilim, Y. (2010). Destination attachment: effects on customer satisfaction and cognitive, affective and conative loyalty. Tourism Management, (31), 274-284.

\section{تأثير المشاركة فى بناء التجربة السياحية على الارتباط بالمقصد السباحي المصرى}

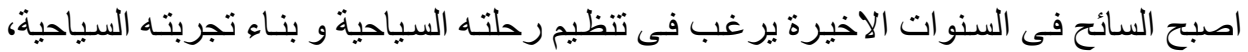

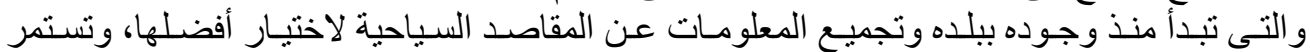

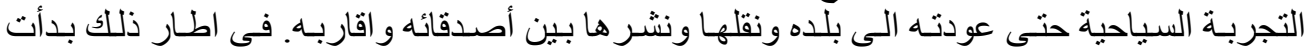

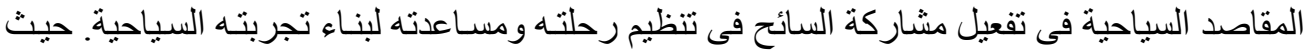

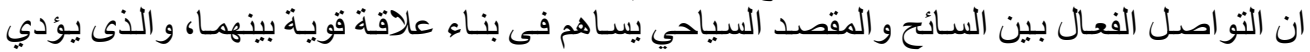

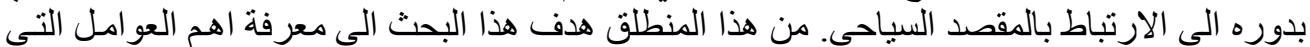

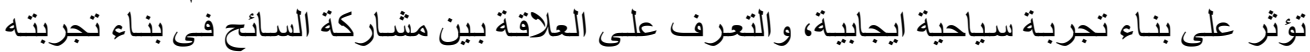

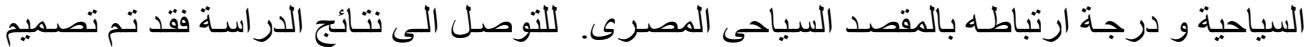

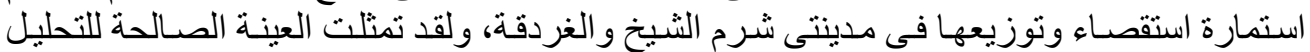

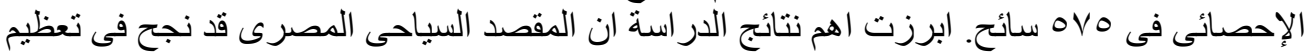

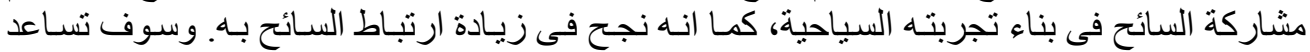

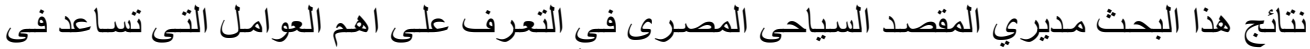

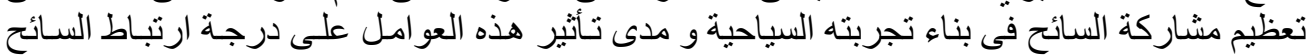

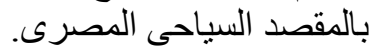

